\title{
BREEDING BIOLOGY AND FLOWER VISITORS OF THE RARE WHITE RIVER PENSTEMON, PENSTEMON SCARIOSUS VAR. ALBIFLUVIS (SCROPHULARIACEAE)
}

\author{
Jennifer S. Lewinsohn ${ }^{1,4}$ and Vincent J. Tepedino ${ }^{2,3}$
}

\begin{abstract}
We studied the breeding system and flower visitors of White River penstemon, a rare endemic from the Uintah Basin of eastern Utah and western Colorado. Bagging treatments and hand-pollination treatments showed that Penstemon scariosus var. albifluvis has a mixed mating system: while some seeds and fruits are produced through selfpollination (both autogamy and geitonogamy), significantly more are produced when flowers are cross-pollinated. The primary flower visitors, and likely pollinators, were several species of native twig- and ground-nesting bees in the families Apidae, Halictidae, and Megachilidae. We found no differences in fruit or seed production between open-pollinated controls and hand-outcrossed flowers, suggesting that pollinator visits were sufficient to maximize female reproductive success. Management plans to conserve White River penstemon must recognize that full reproductive success of this rare plant taxon relies on a suite of pollinating bees, and that the species richness and abundances of bee visitors should be maintained.
\end{abstract}

Key words: Penstemon, reproduction, breeding system, pollinators, bees, pollinator limitation, rarity, reproductive assurance, conservation.

Researchers have frequently hypothesized that pollinator limitation is 1 of the primary forces shaping the reproductive attributes of certain rare plants. Numerous rare plants are thought likely to have developed self-compatibility and autogamy for reproductive assurance (e.g., Levin 1972, Jain 1976; but see Weller 1994, Tepedino 2000). Therefore, studies on sexual reproduction and pollination biology are commonly among the research priorities called for in rare plant recovery plans (Hamrick et al. 1991, Holsinger and Gottlieb 1991, Karron 1991). Basic information on breeding systems and pollinators may also partially explain demographic and genetic characteristics of plant rarity (Hamrick et al. 1991) and, in turn, help to guide management plans.

The genus Penstemon comprises some 275 species (Wolfe et al. 2002), most in the western U.S., many of which are narrow endemics. One of these rarities is the Uintah Basin endemic White River penstemon, Penstemon scariosus var. albifluvis, a candidate for listing under the U.S. Endangered Species Act. Because nothing is known of the reproductive biology of this taxon, our initial objective was to describe its breeding system and test the reproductive assurance hypothesis. Breeding systems in the genus Penstemon range from almost complete self-incompatibility (Tepedino et al. 2006) to a potential for partial autogamy (e.g., Macior 1974, Clements et al. 1999, Tepedino et al. 1999; contact V.J. Tepedino for an unpublished compendium), although all species seem to benefit from pollinator visitation.

Our 2nd objective was to identify floral visitors and determine if fruit production was pollinator limited. Penstemon species are visited by a range of pollinators, including hummingbirds, bees (Wilson et al. 2004), and other insects (Straw 1963), which vary with the suite of floral traits. Flowers of Penstemon scariosus var. albifluvis have characteristics that suggest bee pollination: (1) a bilaterally symmetric, pale lavender to light blue corolla, 18-24 mm long, and (2) production of both pollen and nectar. However, rare plants, more than common congeners, may rely upon atypical pollinators, either because of their rarity (Levin 1972, Tepedino 1979, Karron 1987), or because they occur outside the range of their usual pollinators (Sipes and Tepedino 1996). In addition,

\footnotetext{
${ }^{1}$ Red Butte Garden, University of Utah, 285 South Connor St. \#66A, Salt Lake City, UT 84113.

${ }^{2}$ USDA ARS Bee Biology and Systematics Lab, Department of Biology, Utah State University, Logan UT 84322-5310.

3Corresponding author. E-mail: andrena@biology.usu.edu

${ }^{4}$ Present address: 4513 Park Hill Dr., Salt Lake City 84124.
} 
pollinators and pollination syndromes do not always coincide (e.g., Lange et al. 2000, Castellanos et al. 2003).

\section{Methods \\ Study Site}

White River penstemon is a soboliferous, herbaceous perennial, endemic to the Uintah Basin of Utah and Colorado. It is narrowly restricted to shallow calcareous soils derived from oil shales of the Green River formation (Goodrich and Neese 1986). The breeding system was studied at the type locality on the north bank of the White River, elevation 1520 $\mathrm{m}$; pollinators were observed and collected throughout this site and at an occurrence at the former mining town of Watson (elevation $1630 \mathrm{~m}), 10.5 \mathrm{~km}$ to the south. Both sites encompassed several hundred plants on shale slopes of the Evacuation Creek member of the Green River formation in the Uintah Basin of east central Utah (Uintah Co.). The desert shrub plant community associated with White River penstemon at both sites included Eriogonum brevicaule var. ephedroides (Reveal) Welsh, Forsellesia meionandra (Koehne) Heller, Stipa hymenoides R. \& S., Machaeranthera grindelioides (Nutt.) Shinn., and Cirsium barnebyi Welsh \& Neese. The type locality is under jurisdiction of the Bureau of Land Management, and the Watson site is on private land.

\section{Breeding System}

Field studies were carried out during May and June 2005. To exclude pollinators, we bagged 1 inflorescence with unopened buds on each of 30 haphazardly selected plants, with 1-mm-mesh nylon tulle. Flowers were checked daily for receptive stigmas, indicated by the downward curving style (Straw 1956). Receptive stigmas were pollinated with freshly dehisced anthers, which had been removed from donor flowers with forceps. Stigma surfaces were checked with a hand lens following pollination to confirm transfer of copious pollen. One flower on each inflorescence received 1 of the following 3 treatments: (1) no manipulation (autogamy or parthenogenesis), (2) selfpollination with pollen from another flower on the same plant (geitonogamy), or (3) cross-pollination using a pollen donor at least $10 \mathrm{~m}$ away (xenogamy). Treatments were alternated among flowers to avoid any position effect (Lee 1988).
All flowers were bagged after treatment through anthesis. A 4th treatment, an unbagged, unmanipulated control flower at the same approximate phenological stage as the experimental flowers, was selected on a separate inflorescence, either on the same plant or, occasionally, on a nearby plant. The open-pollinated control served as a comparison with the xenogamy treatment to detect pollinator limitation. Fruit production was compared among pollination treatments using chi-square tests of independence with partitions where appropriate (Maxwell 1961), and seed production per fruit was compared among treatments using l-way ANOVA with Tukey's HSD comparison of means.

\section{Insect Visitors}

In 2005, we observed and collected insect visitors on flowers in both populations, usually at hourly intervals several times during the day. Our purpose was to estimate visitation rates and to collect representatives of important pollinator species for identification. We made no attempt at exhaustive collection; indeed, we tried to minimize our impact on the pollinator community. We also included a limited amount of incidental collecting from 2004. During observation periods, we recorded visitation time, visitor taxon (to the lowest level possible), and number of flowers visited on each plant. Insect specimens were later identified by T.L. Griswold and deposited in the G.E. Bohart Museum of the USDA ARS Bee Biology and Systematics Laboratory, Logan, UT.

\section{RESULTS}

\section{Breeding System}

The results of comparisons among the xenogamy, geitonogamy, and autogamy treatments (Table 1) are both clear and significant $\left(\chi^{2}=27.3, \mathrm{df}=2, P<0.001\right)$. Like most species of Penstemon studied (Tepedino unpublished data), P. scariosus var. albifluvis has mixed-mating capabilities: the species is selfcompatible, but reproductive success is greater when flowers are cross-pollinated. Significantly fewer fruits set without pollinator assistance (autogamy treatment) than in the pollinatorassisted treatments (xenogamy, geitonogamy) combined $\left(\chi^{2}=21.4, \mathrm{df}=1, P<0.001\right)$. Thus, pollinators are required for maximum fruit set. 
TABLE 1. Results of breeding system experiments on Penstemon scariosus var. albifluvis at the White River site, 2005. A = autogamy, $\mathrm{G}=$ geitonogamy, $\mathrm{X}=$ xenogamy, $\mathrm{O}$ $=$ open-pollinated, $s=$ standard deviation. Seed/fruit data were derived only from flowers producing fruit.

\begin{tabular}{lcccc}
\hline & $\mathrm{A}$ & $\mathrm{G}$ & $\mathrm{X}$ & $\mathrm{O}$ \\
\hline Fruit & 4 & 13 & 22 & 23 \\
No fruit & 20 & 10 & 2 & 1 \\
Seed/fruit $(s)$ & $1.75(1.0)$ & $4.0(2.6)$ & $15.3(8.5)$ & $17.3(9.2)$ \\
\hline
\end{tabular}

In addition, fruit set attained by outcrossing (xenogamy) was significantly greater than fruit set from pollinator-assisted selfing (geitonogamy; $\chi^{2}=5.86$, df $=1, P=0.02$ ). Finally, there was no indication that fruit set was pollinator limited (xenogamy versus open-pollinated control treatment; $\chi^{2}=0.36, \mathrm{df}=1$, $P>0.50)$.

The data for seeds per fruit agree with the fruit set data. We found significant differences in the number of seeds produced per fruit among the 4 pollination treatments (Table 1; $\left.F_{3,45}=10.4, P<0.0001\right)$. The only significant differences were between the 2 outcrossing treatments (xenogamy, open) and the 2 selfing treatments (autogamy, geitonogamy; Tukey's HSD: $P=0.05$ ). There was no sign that fruit or seed set were limited by insufficient pollination. Thus, pollinators are required for maximum seed production. Some selfing may occur, but outcrossing produces significantly more seeds per fruit.

\section{Insect Visitation}

In our limited collections we found that Penstemon scariosus var. albifluvis flowers were primarily visited by native, solitary bees. Five genera were identified from our preliminary collections in both populations over the 2 field seasons (Table 2). Two species are of particular interest. One, Osmia sp. ("knowltoni"), is undescribed ("knowltoni" is only intended as a temporary name within this manuscript) and is known only from Utah in Uintah and Millard Counties. Osmia (Melanosmia) may also be undescribed but because we have only 2 specimens, its identity is currently unconfirmed. Surprisingly, although bee specialists are common on other species of Penstemon (e.g., Crosswhite and Crosswhite 1966, Tepedino et al. 1999, 2006), there were few on P. scariosus var. albifluvis. Of the species identified, only O. brevis qualifies as a Penstemon specialist.
The other species of Ceratina and Osmia commonly visit Penstemon flowers but they also visit flowers of many other genera. Of the 12 taxa, 4 nest in the ground, 5 nest in cavities in wood, and the nesting habits of 3 are unknown.

Flowering phenology at the White River site was about 10 days ahead of the Watson site. By the time plants at Watson began to bloom, many plants at White River were done blooming. Because of time constraints, we were able to estimate visitation rates at Watson on only 2 days, so conclusions about differences between sites are premature. Typically, visitation rates to Penstemon species are high (Tepedino et al. 1999, 2006, Wilson et al. 2006), so the low visitation rates at White River compared to Watson were surprising. Nevertheless, visitation rates were still sufficient for each flower to be visited at least once per day on most days (Table 3), and for fruit and seed production to be high (Table 1).

\section{Discussion}

We uncovered few surprises in our study of the breeding system and flower visitors of Penstemon scariosus var. albifluvis. First, as has been found for many other species of rare plants in the western United States (Tepedino 2000), there was no indication that the rarity of White River penstemon has selected for self-compatibility or autogamy as a means of reproductive assurance (Jain 1976). We found that $P$. scariosus var. albifluvis, like other rare and common species of Penstemon (Habroanthus), has a mixed-mating system (Ramstetter and Peterson 1984, McMullen 1998, Tepedino et al. 1999, Lange et al. 2000). Plants are partially self-compatible and weakly autogamous but set significantly more seeds per fruit when outcrossed by pollinators (Table 1). Perhaps the seeming absence of a relationship between breeding systems and reproductive assurance is due to the local abundance of many globally rare plant species (Lesica et al. 2006) and not to competitive disadvantage for pollinator service (Levin and Anderson 1970). Certainly, even rare species of Penstemon commonly grow in fairly dense arrangements and many enjoy high flower visitation rates (Tepedino et al. 1999, 2006, Wilson et al. 2006).

Second, as befits their blue/violet hue and erect orientation on the rachis (Wilson et al. 
TABLE 2. Native solitary bees collected from the flowers of Penstemon scariosus var. albifluvis at White River (WR) and Watson $(\mathrm{WN})$ in mid-May, 2004 and 2005. G = ground-nesting, $\mathrm{C}$ = wood cavity-nesting, $\mathrm{U}=$ nesting habits unknown.

\begin{tabular}{lccc}
\hline Species & Nest & Site & Year \\
\hline Anthophora bomboides Kirby & $\mathrm{G}$ & $\mathrm{WR}$ & 2004 \\
Anthophora dammersi Timberlake & $\mathrm{G}$ & $\mathrm{WR}$ & 2005 \\
Ceratina nanula Cockerell & $\mathrm{C}$ & $\mathrm{WN}$ & 2005 \\
Ceratina pacifica Smith & $\mathrm{C}$ & $\mathrm{WN}$ & 2004,2005 \\
Lasioglossum (Dialictus) sp. & $\mathrm{G}$ & $\mathrm{WR}$ & 2005 \\
Halictus tripartitus Cockerell & $\mathrm{G}$ & $\mathrm{WN}$ & 2005 \\
Osmia brevis Cresson & $\mathrm{U}$ & $\mathrm{WN}$ & 2004 \\
Osmia clarescens Cockerell & $\mathrm{C}$ & $\mathrm{WR}$ & 2005 \\
Osmia ednae Cockerell & $\mathrm{U}$ & $\mathrm{WN}$ & 2004 \\
Osmia sanrafaelae Parker & $\mathrm{C}$ & $\mathrm{WR}$ & 2005 \\
Osmia n. sp. ("knowltoni”) & $\mathrm{C}$ & $\mathrm{WN}$ & 2005 \\
Osmia (Melanosmia) sp. & $\mathrm{U}$ & 2004,2005 \\
\hline
\end{tabular}

TABLE 3. Visits per flower per hour (VFH) to Penstemon scariosus var. albifluvis at White River (WR) and Watson $(\mathrm{WN})$ in 2005. Bees: Dia $=$ Dialictus, Ant $=$ Anthophora, Osm $=$ Osmia, Hal = Halictus, Cer $=$ Ceratina . Flies: Byl $=$ bombyliids.

\begin{tabular}{lcccl}
\hline Date & Site & $\begin{array}{c}\text { Minutes } \\
\text { of observation }\end{array}$ & VFH & Visitors \\
\hline 13 May & WR & 60 & 0 & Dia, Byl \\
14 May & WR & 150 & 0.1 & Dia, Osm \\
15 May & WR & 60 & 1.3 & Dia, Ant, Osm \\
16 May & WR & 90 & 0.8 & Dia, Ant, Osm \\
18 May & WR & 150 & 1.4 & Dia, Osm \\
20 May & WR & 120 & 0.2 & Dia \\
21 May & WR & 30 & 0.6 & Hal \\
25 May & WR & 30 & 0.1 & Cer, Osm \\
23 May & WN & 60 & 4.2 & Cer, Osm \\
\hline
\end{tabular}

2004), flowers of Penstemon scariosus var. albifluvis were primarily visited, and almost certainly pollinated, by native, solitary bees. However, unlike most other bee-adapted Penstemon species, which are usually visited by many species (e.g., Lawson et al. 1989, McMullen 1998, Nielson 1998, Tepedino et al. 1999), we recorded relatively few bee species at the flowers of P. scariosus var. albifluvis (Table 2). This could be because of our limited collecting efforts. However, the relatively low flower visitation rates (Table 3), particularly at the White River site, also suggest that White River penstemon is visited infrequently, at least at some times or places, compared to other Penstemon species.

Third, despite the low species richness of floral visitors and the low flower visitation rates to White River penstemon flowers, there was no indication that seed set was pollinator lim- ited (Table 1). Bee species identical or analagous to the Osmia and Anthophora species captured (Clinebell and Bernhardt 1998, Tepedino et al. 1999, 2006) have been shown to be effective pollinators of other Penstemon species, and our results suggest that their visits to P. scariosus var. albifluvis flowers were equally effective.

Management plans to conserve White River penstemon need to recognize that full reproductive success of this rare plant relies on a full suite of pollinating bees. It is important that the richness of bee species visiting White River penstemon flowers be maintained. A plant species obtains a degree of reproductive assurance when it is visited by a variety of pollinators. This is because bee species typically exhibit large year-to-year fluctuations in abundance (Tepedino and Stanton 1981, Cane and Payne 1993, Williams et al. 2001), though 
species are frequently out of phase with one another; that is, fluctuations in abundance are not necessarily correlated among species; indeed, they may be compensatory. Kremen et al. (2002), for example, have shown that the important native bee pollinators of watermelon differed from year to year on organic farms in California, and that bee diversity was instrumental in ensuring adequate pollination. Kremen (2005) has suggested that at least 2 processes help stabilize pollination services: high species richness-especially important when variation of species' abundances is due to random effects (the portfolio effect) — and density compensation (inverse correlations in population numbers between some species). The greater the diversity in nesting and foraging habits among bee species visiting flowers, the more likely these stabilizing processes are at work. In the suite of species visiting White River penstemon are both xylophilous and fossorial species, generalists and relative specialists, the combination of which strongly supports the stabilization of pollination services. As oil and gas mining in the Uintah Basin proceeds, care must be taken not only to preserve extant populations of the White River penstemon, but also the nesting habitat and secondary floral resources of its pollinators (Tepedino et al. 1997).

\section{ACKNOWLEDGMENTS}

We thank Sylvia Torti, formerly at Red Butte Garden, Salt Lake City, Utah, for initiating this project; Ron Bolander of the USDI BLM, Salt Lake City, Utah, for generously supporting it; Bob Specht and Jean Sinclair, formerly with the USDI BLM, Vernal, Utah, for advice and much logistic help; Mark Dryer for permission to work on land owned by the Cliff Synfuel Corporation; and Terry Griswold, USDA ARS, Logan, Utah, for identifying the bees. Field assistance was ably supplied by Trent Toler, Maria Ulloa, Ariella Murdock, and Paula Longhurst.

\section{Literature Cited}

Cane, J.H., And J.A. Payne. 1993. Regional, annual, and seasonal variation in pollinator guilds: intrinsic traits of bees (Hymenoptera: Apoidea) underlie their patterns of abundance at Vaccinium ashei (Ericaceae). Annals of the Entomological Society of America 86: $577-588$.
Castellanos, M.C., P. Wilson, and J.D. Thomson. 2003. Pollen transfer by hummingbirds and bumblebees, and the divergence of pollination modes in Penstemon. Evolution 57:2742-2752.

Clements, R.K., J.M. Baskin, and C.C. Baskin. 1999. The comparative biology of the two closely-related species Penstemon tenuifloris Pennell and P. hirsutus (L.) Willd. (Scrophulariaceae, section Graciles): II. Reproductive biology. Castanea 64:299-309.

Clinebell, R.R., II, And P. Bernhardt. 1998. The pollination ecology of five species of Penstemon (Scrophulariaceae) in the tallgrass prairie. Annals of the Missouri Botanical Garden 85:126-136.

Crosswhite, F.S., And C.D. Crosswhite. 1966. Insect pollinators of Penstemon series Graciles (Scrophulariaceae) with notes on Osmia and other Megachilidae. American Midland Naturalist 76:450-467.

Goodrich, S., AND E. NeEse. 1986. Uinta Basin flora. USDA Forest Service, Intermountain Region, Ogden, UT.

Hamrick, J.L., M.J.W. Godt, D.A. Murawski, and M.D. Loveless. 1991. Correlations between species traits and allozyme diversity: implications for conservation biology. Pages 75-86 in D.A. Falk and K.E. Holsinger, editors, Genetics and conservation of rare plants. Oxford University Press, New York.

Holsinger, K.E., And L.D. GotTlieb. 1991. Conservation of rare and endangered plants: principles and prospects. Pages 195-208 in D.A. Falk and K.E. Holsinger, editors, Genetics and conservation of rare plants. Oxford University Press, New York.

JAIN, S.K. 1976. The evolution of inbreeding in plants. Annual Review of Ecology and Systematics 7:469-495.

KarRoN, J.D. 1987. The pollination ecology of co-occurring, geographically restricted and widespread species of Astragalus (Fabaceae). Biological Conservation 39: 179-193.

. 1991. Patterns of genetic variation and breeding systems in rare plant species. Pages 87-98 in D.A. Falk and K.E. Holsinger, editors, Genetics and conservation of rare plants. Oxford University Press, New York.

Kremen, C. 2005. Managing ecosystem services: what do we need to know about their ecology? Ecology Letters 8:468-479.

Kremen, C., N.M. Williams, and R.W. Thorp. 2002. Crop pollination from native bees at risk from agricultural intensification. Proceedings of the National Academy of Sciences, USA 99:16812-16816.

Lange, R.S., S.A. Scobell, And P.E. ScotT. 2000. Hummingbird-syndrome traits, breeding system, and pollinator effectiveness in two syntopic Penstemon species. International Journal of Plant Sciences 161: 253-263.

Lawson, H.R., V.J. Tepedino, and T.L. Griswold. 1989. Pollen collectors and other insect visitors to Penstemon haydenii S. Wats. Pages 233-235 in T.B. Bragg and J. Stubbendieck, editors, Proceedings of the 11th North American Prairie Conference. University of Nebraska, Lincoln.

LEE, T.D. 1988. Patterns of fruit and seed production. Pages 179-202 in J. Lovett Doust and L. Lovett Doust, editors, Plant reproductive ecology: patterns and strategies. Oxford University Press, New York.

Lesica, P., R. Yurkewycz, and E.E. Crone. 2006. Rare plants are common where you find them. American Journal of Botany 93:454-459. 
LEvin, D.A. 1972. Competition for pollinator service: a stimulus for the evolution of autogamy. Evolution 26:668-669.

LEvin, D.A., AND W.W. ANDERson. 1970. Competition for pollinators between simultaneously flowering species. American Naturalist 104:455-467.

Macior, L.W. 1974. Pollination ecology of the front range of the Colorado Rocky Mountains. Melanderia 15: $1-59$.

MaXwell, A.E. 1961. Analysing qualitative data. Methuen, London.

MCMullen, A.L. 1998. Factors concerning the conservation of a rare shale endemic plant: the reproductive ecology and edaphic characteristics of Penstemon debilis (Scrophulariaceae). Master's thesis, Utah State University, Logan.

NieLson, R. 1998. Reproductive biology of the rare Harrington's beardtongue, Penstemon harringtonii. Master's thesis, Utah State University, Logan.

Ramstetter, J., and K.M. Peterson. 1984. Pollination biology of Penstemon lemhiensis (Keck) Keck \& Cronq. American Journal of Botany 71 (5, part 2):87 [Abstract].

Sipes, S.D., AND V.J. Tepedino. 1996. Pollinator lost? Reproduction by the enigmatic Jones' cycladenia, Cycladenia humilis var. jonesii (Apocynaceae). Pages 158-166 in J. Maschinski, H.D. Hammond, and L. Holter, editors, Proceedings of the 2nd Southwestern Rare and Endangered Plant Conference, Flagstaff, AZ. General Technical Report RM-GTR-283, USDA Forest Service, Fort Collins, CO.

StraW, R.M. 1956. Adaptive morphology of the Penstemon flower. Phytomorphology 6:112-119.

. 1963. Bee-fly pollination of Penstemon ambiguus. Ecology 44:818-819.

Tepedino, V.J. 1979. The importance of bees and other insect pollinators in maintaining floral species composition. The endangered species: a symposium. Great Basin Naturalist Memoirs 3:139-150.

2000. The reproductive biology of rare rangeland plants and their vulnerability to insecticides. Pages 1-10 in G.L. Cunningham and M.W. Sampson, technical coordinators, Vol. III.5 Grasshopper integrated pest management user handbook. USDA APHIS Technical Bulletin No. 1809, Washington, DC. Available from: http://www.sidney.ars.usda.gov/grasshopper/Handbook/III/iii_5.htm
Tepedino, V.J., W.R. Bowlin, and T.L. Griswold. 2006. The pollination biology of the endangered blowout penstemon (Penstemon haydenii S. Wats.: Scrophulariaceae) in Nebraska. Journal of the Torrey Botanical Society 133:548-559.

Tepedino, V.J., S.D. Sipes, J.L. Barnes, and L.L. HickerSON. 1997. The need for "extended care" in conservation: examples from studies of rare plants in the western United States. Pages 245-248 in K.W. Richards, editor, Proceedings of the International Symposium on Pollination. Acta Horticulturae 437.

TepedinO, V.J., S.D. Sipes, And T.L. GRISwOLD. 1999. The reproductive biology and effective pollinators of the endangered beardtongue Penstemon penlandii (Scrophulariaceae). Plant Systematics and Evolution 219: 39-54.

Tepedino, V.J., and N.L. Stanton. 1981. Diversity and competition in bee-plant communities on short-grass prairie. Oikos 36:35-44.

WeLLER, S.G. 1994. The relationship of rarity to plant reproductive biology. Pages 90-117 in M.L. Bowles and C. Whelan, editors, Recovery and restoration of endangered species. Cambridge University Press. Cambridge, U.K.

Williams, N.M., R.L. Minckley, and F.A. Silveira. 2001. Variation in native bee faunas and its implications for detecting community changes. Conservation Ecology 5(1): [article] 7. http://www.consecol.org/vol5/ iss $1 /$ art7/.

Wilson, P., M.C. Castellanos, J.N. Hogue, J.D. ThomSON, AND W.S. ARmbruster. 2004. A multivariate search for pollination syndromes among penstemons. Oikos 104:345-361.

Wilson, P., M.C. Castellanos, A.D. Wolfe, and J.D. Thomson. 2006. Shifts between bee and bird pollination in penstemons. Pages 47-68 in N.M. Waser and J. Ollerton, editors, Plant-pollinator interactions. University of Chicago Press, Chicago, IL.

Wolfe, A.D., S.L. Datwyler, and C.P. Randle. 2002. A phylogenetic and biogeographic analysis of the Cheloneae (Scrophulariaceae) based on ITS and matK sequence data. Systematic Botany 27:138-148.

Received 26 June 2006 Accepted 7 November 2006 